\title{
Human Rights and the Helsinki Final Act: From USSR to Contemporary Russia
}

\author{
Richard Schifter
}

Published online: 24 November 2012

(C) The Author(s) 2012

Let me begin this presentation with a tribute to Mikhail Sergeyevich Gorbachev. In the years 1987, 1988, and 1989 I visited Moscow every few months and, from visit to visit I saw the totalitarian fog that had hung over the country lift. Undoubtedly, there were many people in the Soviet Union who contributed to that lifting of the fog, but it would not have happened if the person in the top leadership position in the country had not led the way. I believe that Gorbachev is one of the heroes of the cause of freedom in the Twentieth Century.

In the 1960s I had occasion to ask an expert on the Soviet Union how long he thought the Soviet system would last. His response was: "Until the generation that reached political maturity after Stalin's death gets to the top of the ladder." I remembered that remark in 1985, when Gorbachev was elected and checked what his age was when Stalin died. I discovered that he had just turned 22. That left me with the question of whether Gorbachev could be considered to have been politically mature when he reached the age of 22 .

What I discovered a decade later, when I read Gorbachev's Memoirs, is that he reached political maturity at a much earlier age, at the age of 6 , to be precise. What he describes in his memoirs is the arrest, in the course of the 1937/1938 purges of his grandfather, in whose home he lived at that time, on a totally false charge of Trotskyism. He describes how the neighbors began shunning the family's house "as if it were plague-stricken" and that the boys in the neighborhood avoided him. He adds: "All this was a great shock to me and has remained engraved in my memory ever since."

Richard Schifter, Ambassador Special Adviser to the Secretary of State, former USA Representative in the UN Human Rights Commission and at the CSCE Treaty of Helsinki.

R. Schifter $(\square)$

Washington DC, USA

e-mail: ceeun@ceeun.org 
Thus, I would suggest that the drastic changes in governance of the Soviet Union after Gorbachev's accession to power were not the result of the fact that he had outgrown Stalinism, but of the fact that at a very early age he had personally experienced the tragic consequences of Stalinism and had not forgotten them.

As it is, Stalinism, in its most evil form, had come to an end in 1953, not in March, when Stalin died, but in June, when, at a meeting of the Presidium, Lavrenti Beria, Stalin's principal henchman, was arrested. According to what I was told by one of my Soviet colleagues, who heard the account directly from Nikita Khrushchev, the arrest occurred at that meeting, after Beria had pulled out his pistol and Marshal Zhukov had wrestled him to the ground. Beria was executed in December 1953.

What was different about the Soviet Union in the years immediately following Stalin's death and Beria's removal from office was that the system was brought to an end under which a great many loyal supporters of the regime were killed or imprisoned on utterly false charges. But those who did express dissenting views would be charged with "anti-Soviet agitation and propaganda," punishable by up to 7 years of imprisonment and up to 5 years of internal exile or for "defamation of the Soviet system," punishable by up to 3 years of imprisonment and 2 years of internal exile. Participation in a religious sect that was not authorized by the government was also punishable.

Sentences would be meted out under a system known as "telephone justice," under which the local Communist party secretary would call the judge to tell him how to handle a case.

While the practice of charging people with political crimes without credible evidence was ended, the post-Stalin period witnessed the introduction of a new form of punishment for those charged with political crimes or with the unauthorized practice of religion: commitment to an institution for the mentally ill, a practice that became known as "abuse of psychiatry". It appears that if the KGB decided that a case should not be handled by "telephone justice," it would get the signatures of two psychiatrists to declare a dissident mentally ill, suffering from what was called "sluggish schizophrenia."

A significant move forward toward a more open Soviet society took place in 1956, following Nikita Khrushchev's speech denouncing Stalin's “cult of personality." It was a period that became known as "Khrushchev's Thaw." But that period came to an end in 1964, when Khrushchev was deposed and replaced by Leonid Brezhnev. The Soviet Union did not return to Stalinism, but the Thaw came to an end as severe limits on freedom of expression were imposed once again.

But Khrushchev's Thaw did leave an impact on intellectual circles in Soviet society. There was less acceptance of the officially-approved set of beliefs and a greater willingness to take the chance of exchanging dissenting thoughts with friends. By 1970 one of the Soviet Union's outstanding scientists, Andrei Sakharov, began to speak out in criticism as well. He joined with a group of friends to form the Moscow Human Rights Committee. Given his worldwide standing, the penalty imposed on him was less harsh than those imposed on many other dissidents: it was banishment to the city of Gorki, now once again known as Nizhniy Novgorod. 
Young poets, artists, and writers also came together to express their dissent and samizdat, self-publishing, the circulation of unapproved writings, developed. In 1990, I had occasion to address the training institute in Moscow for Communist party cadre on the subject of human rights. After I had spoken, one of the directors of the institute said to me: "In this place we lost our faith 20 years ago."

Totally unrelated to this development of dissenting views, Khrushchev's successor, Leonid Brezhnev, took a step that ultimately led to a significant enlargement of the dissident movement. That was most assuredly an unintended consequence.

What Brezhnev focused on was that World War II had come to an end without a peace treaty between the Allies and Germany. He wanted the borders in Eastern and East Central Europe, including the borders of the DDR recognized. The Soviet Union initially called for a European conference, excluding the United States and Canada, to deal with the recognition of borders in Europe, a conference that would also cover science, technology, art and culture.

The West European states responded favorably, but insisted that the United States and Canada be included in that conference. With the U.S. détente policy in place, the Soviet Union ultimately agreed to a conference that included Canada and the United States. Thus the Conference on Security and Cooperation in Europe convened in September 1972, with Canada and the United States joining the European states. It took close to 3 years to produce an agreement, an agreement that was signed on August 1, 1975 in Helsinki and became known as the Helsinki Final Act.

In the negotiations that led to agreement on the Helsinki Final Act, it was the European states that took the lead for the West, particularly for the inclusion of what became known as the Third Basket, the human rights provisions. The United States played a relatively passive role in the negotiations.

Given the Final Act's confirmation of the post World War II borders of all European states, the Soviet leadership considered the agreement a huge diplomatic success. Accordingly, copies of the Final Act were given wide distribution in the Soviet Union. What the leadership appears not to have anticipated is that many Soviet citizens would read all parts of the document and would note that Leonid Brezhnev had signed an agreement that provided in Article VII for "Respect for Human Rights and Fundamental Freedoms, Including the Freedom of Thought, Conscience, Religion, and Belief."

One of those who read the agreement in full was Yuri Orlov, a physicist. He reached out to friends and discussed formation of an organization whose purpose it would be to attain the goals so clearly spelled out in the Helsinki Final Act, a document that, after all, had been signed by the Soviet Union's principal leader. To underline the fact that the purpose of the new organization was to do nothing other than to carry out the policy agreed to by the Soviet Government, the new group called itself the "Public Group to Promote Fulfillment of the Helsinki Accords in the USSR." (It subsequently became known as the Moscow Helsinki Watch Group). Though Andre Sakharov did not join the new organization, he allowed its formation to be announced to the press in his apartment, which made it more likely that it 
would receive international publicity, which it did. The new group then committed itself to the task of publicizing Soviet violations of the Helsinki Accords.

It did not take long for the KGB to respond. Orlov was arrested in 1977, was convicted and given the maximum 12-year sentence for anti-Soviet agitation and propaganda. Many other members of Moscow Helsinki Watch faced a similar fate. (Orlov did not serve the full sentence. In 1986, after Gorbachev's accession, he was deported to the United States, in exchange for U.S. release of a Soviet spy).

Under the provisions of the Helsinki Final Act, the parties agreed to hold periodic meetings "to continue the multilateral process initiated by the Conference." The first such meeting was scheduled to take place in Belgrade in 1979. It was at the Belgrade meeting that the United States, for the first time, pressed hard and publicly on the issue of the violations by the Soviet Union of the human rights provisions of the Helsinki Final Act. That process was continued at the second follow-up meeting, in 1981, in Madrid.

The Belgrade and Madrid CSCE meetings put the violations of the human rights provisions of the Helsinki Final Act by the Soviet Union and by other members of the Warsaw Pact at the very top of the list of issues on which the Communist East European states and the West found themselves in profound disagreement. That disagreement remained in place as Brezhnev was succeeded by Andropov, who, in turn, was succeeded by Chernenko.

And then, in April 1985, after Chernenko's death, Mikhail Gorbachev was elected General Secretary of the Central Committee of the Communist Party of the Soviet Union. In the West note was taken of the fact that Prime Minister Thatcher of the United Kingdom, who had met Gorbachev in London in 1984 had said that he was a man "you could do business with." It was also noted, however, that Foreign Minister Gromyko had spoken of Gorbachev as a man with a nice smile but iron teeth.

Those of us in the United States Government who focused on the Soviet Union and who were looking for changes under the new leadership did not notice any significant change for some time. To be sure, in July Andrei Gromyko was replaced as Foreign Minister by Eduard Shevardnadze, but we thought that this could be due to the fact that Gromyko had served as Foreign Minister for 28 years and was being replaced by someone who was 19 years younger.

The first encounter between the Soviet Union's new leader and the President of the United States, Ronald Reagan, took place in Geneva in November 1985. The meeting's principal focus was on arms reduction, but Reagan used the opportunity to raise human rights concerns as well. He was rebuffed. It took close to 2 years before we saw some evidence that there was indeed a chance of change in the Soviet Union under Gorbachev's leadership.

It all started very inauspiciously, on December 19, 1986, with a knock on the door of an apartment in Gorki. As Yelena Bonner, Sakharov's wife, opened the door, there stood two workmen who told her that they had been ordered to install a telephone in the apartment. They proceeded to do just that. Shortly thereafter the phone rang. As Andrei Sakharov picked up the phone, he heard the voice of the General Secretary, who invited him to return to Moscow. The news of the telephone call made the rounds worldwide. 
A few weeks later there came another significant news item from the Soviet Union: a large number of political prisoners had been released from the GULAG. It was clear that we were seeing movement in the Soviet Union toward a more open society.

It was in early 1987 that Secretary Shultz decided that the time was ripe to initiate a serious dialogue with the Soviet Union on arms reduction. To underline the interest of the United States in compliance of the Soviet Union with international human rights standards, Shultz decided to take me, the U.S. Assistant Secretary of State for Human Rights, along on a visit to Moscow for discussion of arms control. On his arrival in Moscow, he suggested to Shevardnadze that a human rights dialogue be started and Shevardnadze agreed.

It took a while for this dialogue to get off the ground, but in September 1987, I had a highly significant conversation with a Soviet foreign ministry official. He conceded that abuse of psychiatry had taken place in the Soviet Union and told me that it had been brought to an end. Another important step forward was taken in early 1988, when I was told that the Soviet Union intended to bring itself into full compliance with its international human rights obligations. By the end of 1988, as far as we could tell, all persons incarcerated for political crimes or the unauthorized practice of religion had been released from prison. The Soviet Union was clearly on its move toward a democratic, open society.

These profound changes in the Soviet Union were greatly appreciated by President Reagan and Secretary Shultz. A very close personal relationship of mutual trust developed between Reagan and Gorbachev and between Shultz and Shevardnadze. In January 1989, the third CSCE follow-up meeting in Vienna came to a satisfactory conclusion, with all members in full agreement on the principles of human rights.

While the Soviet Union under Gorbachev was making significant progress on the political front, that was, regrettably, not true on the economic front. The Soviet Union's command economy had never worked well. Gorbachev had inherited a set of serious problems, but had not found a way to coping with them. I thought in 1989 that the United States and Western Europe should join in creating a new Marshall Plan to provide assistance to the new democratic Soviet Union to enable it to end the command economy in an orderly systematic way, a way that would minimize the burdens born by the country's citizens. But that was not to be. The democratization of the country had added to the inefficiency of the command economy and the standard of living continued to decline.

It was this economic failure that caused Gorbachev to lose support throughout the country. Many of those who had favored the policies that moved the country toward democracy shifted their support to Boris Yeltsin. Yeltsin, in turn, thought that he could attain a top leadership position by attaining the Presidency of Russia and then joining with other presidents of Soviet Republics in dissolving the Soviet Union. He reached that goal in December 1991.

Russia under Yeltsin retained Gorbachev's political reforms. To confront the country's economic problems, Yeltsin moved forward with the privatization of government-owned economic enterprises. The goal of privatization was indeed reached, but it was done in a disorganized and corrupt fashion. Much of the 
government appeared disorganized. Yeltsin gave democracy a bad name among many average Russians.

Under Vladimir Putin, who became President in 2000, order was restored, but at a price. The open society created under Gorbachev is gone. We are not back to the Brezhnev era, but the media and civil society are once again governmentally controlled, and the electoral system is rigged. While we do not witness abuse of psychiatry or convictions for anti-Russian agitation and propaganda, the killings or injuring of news reporters or other enemies of the leadership, and the failure to find perpetrators are indeed very troublesome.

Once again we find that many members of the intelligentsia are greatly troubled by the repression of fundamental freedoms, but it would seem that a majority of the population at large is satisfied with the restoration of order and the operation of the economy.

As I am writing these observations and as I have made reference to general popular attitudes in Russia, let me conclude with a few comments about my great admiration for the truly humanitarian outlook that characterizes, even in condition of civil war, the most culturally advance and countries. I want to talk of my experience in a former enemy country where the history and the intellectual heritage impeded to the Fascit-Nazi regime to get the mind and heart of the main great part of the Italian people, even of the loyal Carabinieri Army elite brigades. Noble memories of my long life that are telling and have great relevance even more in nowadays world.

As World War II ended I was serving as an American soldier in Germany. I decided then to search for surviving relatives in Europe and discovered that a cousin of mine had survived in Pisa. I decided to visit him, flew from Frankfurt to Rome and then to Pisa. My cousin, who had gone to medical school in Pisa, had decided years earlier to stay there to practice medicine.

What he told me when I met him was that in November 1943 he had received a notice to report to the local Carabinieri office. When he arrived there, he was directed to a room in which members of other Jewish families in Pisa were assembled. Before long, the head of the Pisa Carabinieri force walked into the room, pulled out a letter from his pocket and said: "I have received instructions from Gestapo headquarters in Firenze to arrest all of you and your families and to transport you to Firenze to turn you over to the Gestapo. But I have no trucks today, go home and we'll arrange for you to come next week."

A patient of my cousin who had a brother in a nearby mountain village very promptly arranged for my cousin and his family to move to a hut in the forest near that village. The villagers provided food and other necessities to the family and my cousin, in turn, provided the villagers with medical care. After the war, my cousin opened a clinic in the village and spent 1 day a week there to take care of the people who had saved his and his family's life.

I know that throughout Italy there were many similar such occurrences in which people, including Italian officials, demonstrated their humanity. In fact Italy came out from the war with the dignity to have paid the price of the Mussolini's regime with a winning civil war and a new real, successful European democracy, became in 1957 a founder of the European Union with the Treaty of Rome. 